\title{
The Effectiveness of Teachers' Use of Lecture Model Combined with Cooperative Learning Method for Enhancing Students' Problem-Solving Skills in Physics
}

\author{
Rahmi Putri Za) Jumadi, Ariswan, Ratnasari, Depi Oktasari \\ Universitas Negeri Yogyakarta \\ a)rahmiputriz09@gmail.com
}

\begin{abstract}
This study investigates the effect of the use of teachers' Lecture models combined with cooperative learning methods to improve students' problem-solving skills in physics compare with the control group who were not exposed to the lecture model combined with cooperative learning methods from effect size value. The research method was a quasi-experimental research. The sample consisted of 33 students of 10th grade in middle schools (senior high school), SMAN 1 Sungai Penuh, Jambi Province where they ware learn at work and energy concept. Students' achievements, as well as their problem-solving skills of work and energy concept were assessed by pretest-posttest with an essay test. The results showed that the experimental group's learning process has a high effect size value to problem-solving skills more than control group learning process. That shows the lecture model combined with cooperative learning method more effective than lecture model.
\end{abstract}

Keywords: lecture model, combined with, cooperative learning method, problem-solving skills, physics education

\section{INTRODUCTION}

Until now, the lecture learning model still using by teachers in class. Malik et al. (2017), from initial research known that teachers still using the lecture model in learning dominantly then another model. Where students need to hear teacher explanation and made a teacher as only one source of learning/teacher-centered. There are many things to be the reason why a teacher can not change that model learning. One of that because there are so many materials they need to achieve for one semester, and that will be effective if they use the lecture model to efficient the time. The issue of content coverage which is considered one of the critical issue or strong argument by supporters of traditional instruction (Ahmed 2010), where the teacher often need almost all of the lecture slots to deliver the content (Ronchetti 2010). The lecture model may be one of the popular learning models in different subject of course (Kaur 2011).

In Indonesia, there is much research about how the lecture model does not effective for physics class. The results show that students have low cognitive grades in physics because of that learning model. However, there are still many teachers using the lecture model. In other said, in curriculum 2013, the teacher needs to lead student in active learning. Because of that, we need to modify that model so that will be effective for physics learning. Khairati, Feranie, \& Karim (2016) explained that each student has different level of metacognition, because of that teacher need to combined model learning that can make student active in group learning so that they can improve their metacognitive ability. 
Moreover, in study group, student can have opportunity to discuss their ideas with other friends to make a better solution. There is research from Johnson \& Mighten (2005) was covered that learning with lecture note combined with structure groups discussion more effective than lecture only.

Furthermore, Mohammadjani \& Tonkaboni (2015) explained that cooperative learning method gives a better effect than lecture learning methods. Moreover, they explained that students have higher satisfaction with cooperative learning methods than lecture methods. Warfa (2016) found that cooperative learning can increase student achievement by 0,68 standard deviations and explained that achievement better than student in a traditional class. Hyun, Ediger, \& Lee (2017) explained the learning pedagogy activities give a significant factor. It causes increasing the students' satisfaction with their learning processes; group and individually. Azizan et al. (2018) explained that Cooperative learning strategy using complex instruction method has successfully made the students moved up to another level of understanding the subject matter and in addition to that, empowering the teamwork skills among the students and nurturing their creativity.

In this study, we modified the lecture model, with combined it to cooperative learning method. The main goal was to investigate the effectiveness of using a lecture model combined with teamwork presentation by students in the context of teaching and learning concepts of work and energy in secondary school physics.

State of the literature:

- The lecture model was one of the models that give a bed mindset where it applies in physics class where students always in a passive position. Most research on lecture model ware showing the lecture model do not effective in class, but few studies discuss modified the lecture model learning to be an effective model learning.

- There was very little research about using a lecture model combined with other methods like cooperative learning methods to enhance students' problem-solving skills.

Contribution of this paper to the literature:

- This study was the focus on the lecture model combined with the cooperative learning method by students' effect on students' problem-solving skills in middle schools (10th senior high school) Jambi province, Indonesian schools.

- The study found that the lecture model combined with the cooperative presentation method is relatively better than the lecture model in enhancing students' problem-solving skills, even though there are not the statically significant value from that two model learning.

\section{Lecture Model Combined with Cooperative learning method}

There is a lecture model or called by the traditional model is a model of instruction that requires a student with a passive position. Where an instructor-centered classroom setting in which students are more passive listeners than active learning (Miller, McNear, \& Metz 2013). In this model, the teacher is delivery the knowledge by talking in a class where student be passive recipients of knowledge (Zakaria, Ikhsan 2007).

The cooperative learning method is a method of study where the student works together to complete the task and sharing ideas to solve the problem. Zakaria \& Ikhsan (2007) explain that cooperative learning is grounded in the belief that the most effective learning when students are actively involved in sharing ideas and work cooperatively to complete an academic task. There is cooperative learning enhances perspective teachers' academic achievement as compared to traditional instruction and promotes enriched, enjoyable, and interactive learning experience (Ahmad 2010) and has a positive effect on students' academic achievement (Gull, Shehzed 2015) while Foldnes (2016) states that the classroom flip if implemented adequately with cooperative learning, can lead to increased academic performance.

There is a lecture model, and cooperative learning has a different function. Where lecture model or called by traditional model appropriate for lecture delivery, and cooperative learning as active learning appropriate for student engagement (Hyun, Ediger, \& Lee, 2017). There is in this study, did with combined lecture model and cooperative learning with problem sets structure, so that will allow a teacher to do lecture delivery and students can sill active in learning with participating in cooperative learning. Felder \& Brent (2007) state that cooperative learning can be used in any type of assignment that can be given to students in lecture classes, laboratories, or project-based courses. 
A cooperative learning method with problem sets structure did students by group, where students complete some of their assignments in teams (Felder \& Brent, 2007). There is problem set given by teacher after the delivery concept of subjects study or give a lecture to students.

There is from the explanation above, can be explained that in this research lecture model did combine with cooperative learning method was did by some steps: 1) Teacher deliver the material with talk, 2) After giving explanation about material teacher divide student in some group, 3) Each group with cooperative learning, problem sets structure, discuss some problem (minimal 2 problems) related to the material study, 4) Each group by turns give a presentation about some problem that they discussed before and give the explanation about the answer of the problem, 5) other groups can ask some question to a group that gives presentation about the problem if there do not understand about explanation, 6) The group presentation give feedback about question, 7) Conclusion, where teacher and students together make the conclusion.

\section{Problem Solving Skill}

In the 21 st century, there is a need for learning and innovation skills to teach for the student. There are creativity and innovation, critical thinking and problem solving, communication and collaboration (The Partnership for 21st Century Skills 2009). Physics learning needs to support students to acquire problem-solving which are relevant to their daily life (Argaw et al. 2016). Cooperative learning help student to develop their problem-solving skills. Temur (2012) state that when teacher encourages the student to participate in an activity and they can share their mathematical ideas within a group. It might be more effective than the lecture of the teacher during problem-solving process.

There are fundamental problem-solving skills include: 1) the ability to define the problem, 2) pick an appropriate strategy to solve the problem, 3) plan steps for completion, 4) implement those steps, and 5) reflect on the process when it is finished (Knapp, Glenn 1996). There are steps, then using as indicators and steps in answer the problem in a test which giving in pretest-posttest. Student makes a test with:

TABLE 1. Indicator of Problem Solving Skills

\begin{tabular}{|c|c|c|}
\hline & Indicator & Aspect of test \\
\hline 1) & The ability to define the problem & $\begin{array}{l}\text { Students write about what the knowing and asking from the } \\
\text { problem that was given }\end{array}$ \\
\hline 2) & $\begin{array}{l}\text { pick an appropriate strategy to solve the } \\
\text { problem, }\end{array}$ & $\begin{array}{l}\text { Students use their knowledge to pick the formula to solve the } \\
\text { problem and make a plan step to using the formula to solve the }\end{array}$ \\
\hline 3) & plan steps for completion, & problem. \\
\hline 4) & implement methode steps & $\begin{array}{l}\text { Students do problem-solving appropriate to plan step that was } \\
\text { written before. }\end{array}$ \\
\hline 5) & reflect on the process when it is finish & $\begin{array}{l}\text { The student did check again with answer from step before and } \\
\text { make sure that is right with writing the summary from the answer. }\end{array}$ \\
\hline
\end{tabular}

\section{Research Questions}

T study is to investigate the effectiveness of using the lecture model combined with cooperative learning method in the context of teaching and learning concepts of work and energy in secondary school physics. For more specific, there are two interests research questions as follows:

1. How significant effect size value at the experiment group and control group?

2. Is there a significant difference in students' problem-solving skills between the experiment group and control group?

\section{METHODS}

\section{Method}

This experiment was one group pretest-posttest, where the lecture model combined with cooperative learning method was implemented in the experiment class and lecture model in the control class. Where the step of model ware:

TABLE 2. Step of study 


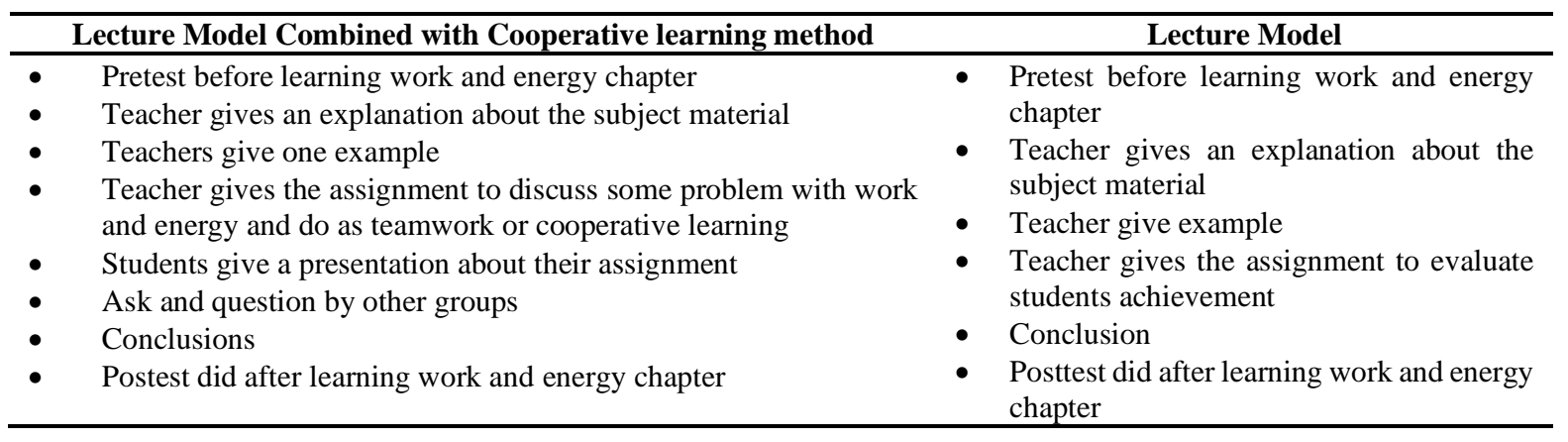

\section{Subject}

The participant in this study consisted of two groups: an experimental $(\mathrm{N}=33)$ and a control $(\mathrm{N}=30)$. All two classes (10th grade) were from same the same high school in an Indonesia educational, located in Jambi province.

\section{Research Instruments}

The instrument in this research was using an essay test. The test consisted of 5 essay questions where the answer must write by sequence consider problem-solving skills. The test was content validity by seven experts with a physics education background. The validity value of 5 essay question is in a valid category where V'Aiken showed that has one marks for content validity.

\section{Analysis Method}

Analysis of the general linear model was used to know the effect size of the learning model on problem-solving skills. There is the effect size value read in table partial Etta square of multivariate tests and the significant value in tests of within-subjects effects table. The value was significant if sign $<0,05$ (Widhiarso 2011).

\section{RESULTS AND DISCUSSIONS}

This research was conducted at SMA Negeri 1 Kota Sungai Penuh, Jambi Province in class X. Learning was conducted with modifying the lecture model combined with cooperative learning method. The lecture model combines with cooperative learning method was did by some steps: 1) Teacher deliver the material with talk, 2) After giving explanation about material teacher divide student in some group, 3) Each group with cooperative learning, problem sets structure, discuss some problem (minimal 2 problems) related to the material study, 4) Each group by turns give a presentation about some problem that they discussed before and give the explanation about the answer of the problem, 5) other groups can ask some question to a group that gives presentation about the problem if there do not understand about explanation, 6) The group presentation give feedback about question, 7) Conclusion, where teacher and students together make the conclusion.

After study, the whole part of material, the class experiment, and class control did a posttest. There is effect size value can be seen column Partial Etta squared in TABLE 3. While TABLE 4 presents the significant value. From table 2 shows there was no significant difference between experiment and control class where sign $0,787>0,05$. 
TABLE 3. Multivariate Tests

\begin{tabular}{llllll}
\hline KELAS & & F & Error df & Sig. & Partial Eta Squared \\
& & & & & \\
\hline \multirow{2}{*}{ EXPERIMENT } & Pillai's trace & $174.745^{\mathrm{a}}$ & 61.000 & .000 & .741 \\
& Wilks' lambda & $174.745^{\mathrm{a}}$ & 61.000 & .000 & .741 \\
& Hotelling's trace & $174.745^{\mathrm{a}}$ & 61.000 & .000 & .741 \\
& Roy's largest root & $174.745^{\mathrm{a}}$ & 61.000 & .000 & .741 \\
\hline & Pillai's trace & $149.557^{\mathrm{a}}$ & 61.000 & .000 & .710 \\
& Wilks' lambda & $149.557^{\mathrm{a}}$ & 61.000 & .000 & .710 \\
CONTROL & Hotelling's trace & $149.557^{\mathrm{a}}$ & 61.000 & .000 & .710 \\
& Roy's largest root & $149.557^{\mathrm{a}}$ & 61.000 & .000 & .710 \\
\hline
\end{tabular}

The comparison effect size value between experiment and control class can be seen in FIGURE 1.

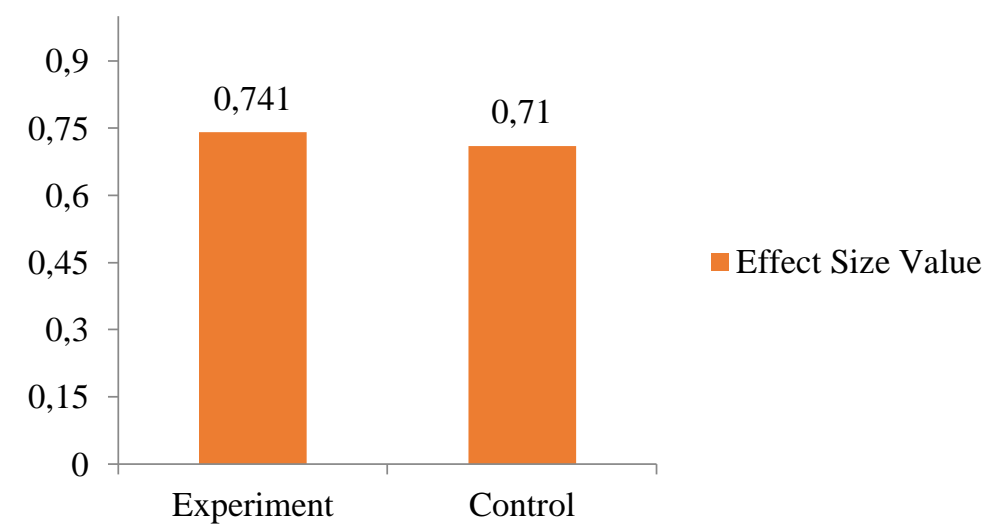

FIGURE 1. Comporison of Effect Size Value in experiment and control class

The result was related to second question based on TABLE 4.

TABLE 4. Tests of Within-Subjects Effects

\begin{tabular}{|c|c|c|c|c|}
\hline & ource & $\mathrm{F}$ & Sig. & Partial Eta Squared \\
\hline \multirow{4}{*}{ time } & Sphericity Assumed & 323.029 & .000 & .841 \\
\hline & Greenhouse-Geisser & 323.029 & .000 & .841 \\
\hline & Huynh-Feldt & 323.029 & .000 & .841 \\
\hline & Lower-bound & 323.029 & .000 & .841 \\
\hline \multirow{4}{*}{ time $*$ KELAS } & Sphericity Assumed & .073 & .787 & .001 \\
\hline & Greenhouse-Geisser & .073 & .787 & .001 \\
\hline & Huynh-Feldt & .073 & .787 & .001 \\
\hline & Lower-bound & .073 & .787 & .001 \\
\hline \multirow{4}{*}{ Error(time) } & Sphericity Assumed & & & \\
\hline & Greenhouse-Geisser & & & \\
\hline & Huynh-Feldt & & & \\
\hline & Lower-bound & & & \\
\hline
\end{tabular}


From the study that did before, we got some problems with students' complains. Some students said they ware not understand the problem and not confident in giving explanation about their problem and the answer. So to make it better, there are some activity that teacher can do: 1) teacher can facilitate all group with much of source material study so students can learn better by themselves, like make module with in-depth explanation, 2) teacher can give feedback after students give explanation to answers and make it students confident with their answer, so they motivate to do better, 3) teacher need to use the model continuously so student feel comfortable with the learning process and teacher can see the better students progress.

From the finding we can see, the value of effect size in the experiment class is 0,741 and the value of effect size in control class is 0,710 . That means is in-class experiment, lecture model combined with cooperative learning method by students implementation gives effect to enhance problem-solving skills to $74,1 \%$ students of the class. While in class control, lecture model implementation gives effect to enhance problem-solving skills to $71 \%$ of students. From cohen (1988) there is score 0,7 is in the medium category of effect size. While, 0, 2 "small", and 0,8 "big" category. From the data above, we have known that class experiment has bigger effect size than control class. That is along with Mohammadjani, \& Tonkaboni (2015) results from research that cooperative learning teaching method has a higher effect on students learning than lecture teaching. Temur (2012) states that when a teacher encourages the student to participate in an activity and they can share their mathematical ideas within a group might be more effective than the lecture of the teacher during problem-solving process.

Significant value is 0,787 , where sign $>0,05$. Despite the effect size value of experiment class is bigger than the control class, there was no significant difference between experiment class and control class in enhancing students' problem-solving skills. There is from another research state that is students' attitude to active learning; experiential learning is significantly more positive than attitude to lecture course (Pugsley, Clayton 2003).

There is no significant difference maybe because of some reason:

1. The student who does not understand the concept makes it like they did not try their best to make a good presentation about the problem. That was can to be seen by the teacher, where the group who give a presentation can not answer the question of other groups in class. There is for better understanding of the concept teachers need to give follow up to students' presentations (Luangrath, Petterrson 2012).

2. There are some students who still do not participate in a group discussion or cooperative process. So that makes the process of learning did not enhance students' problem-solving skills maximally. Luangrath \& Petterson (2012) state that to improve a group discussion or in this study cooperative learning, the student should also be informed about the essence of working in a group.

3. The student still needs to adapt with the lecture model combined with cooperative learning and need more time to did cooperative learning. There is a result of research Suardi \& Kanji (2018) with tittle "lecture model of student transfer discussion method to increase student's activeness and learning outcome was explained that students who not yet enhance their learning outcome was because of students are still adapt with lecture model and the time required to conduct the student transfer discussion model.

4. The student still not accustomed to solving the problem appropriate to the problem-solving step. From the study before explaining that are needed to give training for students and teachers in recent problem-solving strategies besides using active learning methods (Eshetu \& Assefa 2019). Although the values obtained have not differed significantly, we can still consider the benefits that can be obtained based on the combined lecture learning model with cooperative learning methods, including:

1. The student can still active in the learning process through teamwork activity, group discussion, and sharing ideas to solve the problem. Emerson, English, \& McGoldrick (2016), despite the less positive impression of some students regarding cooperative learning, but still cooperative learning activities facilitating increased interaction among certain types of students who might not otherwise interact with classmates.

2. There is an activity with lecture model learning combined with cooperative learning methods support students in understanding concepts better, where the teacher can delivery knowledge 
extensively, and students can understand it better in their language through discussion problems solving activity with their respective groups.

Felder, \& Brent (2017) state that advantages of cooperative learning are: 1) students learn more active with teamwork than by simply watching and listening, that is an active method, 2) cooperative learning can help weak students in learning, where strong students can help them in the study, 3) student who in-group will motivate to complete their assignment on time because they know that others are counting on them. So, there are utilization and implementation of the lecture model combined with cooperative learning methods need to do in a long time to get better learning outcome.

\section{CONCLUSIONS}

From effect size value, we are known that the lecture model combined with the cooperative learning method is more effective than the lecture model. There is no significant difference between lecture model combined with the cooperative learning method and lecture model. Students' lack of teamwork in cooperative learning methods may be one of the challenges in using cooperative learning. There are some suggestion for other researchers in using lecture model combined with cooperative learning method in further research that is: 1) teacher need to give better understanding to students about what they need to do in cooperative learning, and always there to supervise the activity of students, 2) prepared the environment that made students want to share their ideas and work together to solve the problem, 3) future research need to do in bigger sample and can do comparison of different model of cooperative learning, 4) cooperative learning intervention should be given for a long time period to get the better effectiveness.

\section{REFERENCES}

Ahmad, Z, Mahmood, N 2010, 'Effect of Cooperative Learning vs. Traditional Instruction on Prospective Teachers' Learning Experience and Achievement', Ankara University, Journal of Faculty of Education Sciences, vol. 43, no. 1, pp. 151-164.

Argaw, AS, Haile, BB, Ayalew, BT, \& Kuma, SG 2016, 'The Effect of Problem Based Learning (PBL) Instruction on Students' Motivation and Problem Solving Skills of Physics', Eurasia Journal of Mathematics Science and Technology Education, vol. 13, no. 3, pp. 857-871. DOI 10.12973/eurasia.2017.00647a

Azizan, MT, Mellon, N, Ramli, RM, \& Yusup, S 2018, 'Improving teamwork skills and enhancing deep learning via development of board game using cooperative learning method in reacting engineering course', Educational for chemical engineers, vol. 22, no. 1, pp. 1-13. DOI: 10.1016/j.ece.2017.10.002

Cohen, J 1988, Statistical Power Analysis for the Behavioral Sciences (2th Edition), Lawrence Erlbaum Associates, United States of America.

Emerson, TLN, English, L, \& McGoldrick, K 2016, 'Cooperative Learning and Personality Types', International Review of Economics Education, vol. 21, pp. 21-29. DOI: http://dx.doi.org/10.1016/j.iree.2015.12.003

Eshetu, F, Assefa, S 2019, 'Effects of Context-Based Instructional Approaches on Students' ProblemSolving Skills in Rotation Motion', EURASIA Journal of Mathematics, Science and Technology Education, vol. 15, no. 2, pp. 1-13. https://doi.org/10.29333/ejmste/102283

Felder, RM, \& Brent, R 2007, Cooperative Learning', P.A. Mabrouk, ed., Active Learning: Models from the Analytical Sciences, ACS Symposium Series 970, Chapter 4, American Chemical Society, Washington DC.

Foldnes, N 2016, 'The Flipped Classroom and Cooperative Learning: Evidence from a Randomised Experiment', Active Learning In Higher Education, vol. 17, no. 1, pp. 39-49. DOI: $10.1177 / 1469787415616726$ 
Gull, F, \& Shehzed, S 2015, 'Effects of Cooperative Learning on Students' Academic Achievement', Journal of Education and Learning, vol. 9, no. 3, pp. 246-255.

Hyun, J, Ediger, R, \& Lee, D 2017, 'Students' Satisfaction on Their Learning Process in Active Learning and Traditional Classrooms', International Journal of Teaching and Learning in Higher Education, vol. 29, no. 1, pp. 108-118. ISSN: 1812-9129.

Johnson, JP, Mighten, A 2005, 'A Comparison of Teaching Strategies: Lecture Notes Combined with Structured Group Discussion Versus Lecture Only', Journal of Nursing Education, vol. 44, no. 7, pp. 319-322.

Kaur, G 2011, 'Study and Analysis of Lecture Model of Teaching', International Journal of Education Planning \& Administration, vol. 1, no. 1, pp. 9-13.

Khairati, IA, Feranie, S, \& Karim, S 2016, 'Penerapan Strategi Metakognisi pada Cooperative Learning untuk Mengetahui Profil Metakognisi dan Peningkatan Prestasi Belajar Siswa SMA pada Materi Fluida Statis', JPPPF (Jurnal Penelitian \& Pengembangan Pendidikan Fisika), vol. 2, no. 1, pp. 65-72. DOI: doi.org/10.21009/1.02110

Knapp, LR, Glenn, AL 1996, Restructing School with Technology, Allyn \& Bacon, Massachusetts.

Luangrath, P, Pettersson, S 2012, 'Problems and Possibilities with Centering Physics Teaching around Student Discussions', Eurasia Journal of Mathematics, Science \& Technology Education, vol. 8, no. 3, pp. 189-200. DOI: 10.12973/eurasia.2012.834a

Malik, A, Oktaviani, V, Handayani, W, \& Chusni, MM 2017, 'Penerapan model process oriented guided inquiry learning (POGIL) untuk meningkatkan keterampilan berpikir kritis peserta didik', JPPPF (Jurnal Penelitian \& Pengembangan Pendidikan Fisika), vol. 3, no. 2, pp. 127-136. DOI: doi.org/10.21009/1.03202

Miller, CJ, McNear, \& Metz, MJ 2013, 'A Comparison of Traditional and Engaging Lecture Methods in a Large, Professional-level Course', Adv Physiol Educ, vol. 37, pp. 347-355. doi:10.1152/advan.00050.2013

Mohammadjani, F, Tonkaboni, F 2015, 'A Comparison between the Effect of Cooperative Learning Teaching Method and Lecture Teaching Method on Students' Learning and Satisfaction Level', International Education Studies, vol. 8, no. 9, pp. 107-112. ISSN 1913-9020 E-ISSN 1913-9039

Pugsley, KE, Clayton, LH 2003, 'Traditional Lecture or Experiential Learning: Changing Student Attitudes', Journal of Nursing Education 42(11), pp 520-523.

Ronchetti, M 2010, 'The VOLARE Methodology: Using Technology to Help Changing the Traditional Lecture Model', Tech-Education, CCIS 73, pp. 134-140.

Suardi, Kanji, H 2018, 'Lecture Model of Student Transfer Discussion Method to Increase Student's Activeness and Learning Outcomes', EST Journal of Educational Science and Technology, vol. 4, no. 1, pp. 48-54. DOI: http://dx.doi.org/10.26858/est.v4i1.4814

Temur, OD 2012, 'Analysis of Prospective Classroom Teachers' Teaching of Mathematical Modeling and Problem Solving', Eurasia Journal of Mathematics, Science \& Technology Education, vol. 8, no. 2, pp. 83-93. ISSN: 1305-8223

The Partnership for 21st Century Skills 2009, P21 Framework Definition's.

Warfa, ARM 2016, 'Using cooperative learning to teach chemistry: A meta-analytic review'. Journal of chemical education, pp. 1-8. DOI: 10.1021/acs.jchemed.5b00608

Widhiarso, W 2011, Aplikasi Anava Campuran untuk Desain Eksperimen Pre-Post Test Design, Fakultas Psikologi Universitas Gajah Mada, Yogyakarta.

Zakaria, E, Ikhsan, Z 2007, 'Promoting Cooperative Learning in Science and Mathematics Education: A Malaysian Perspective', Eurasia Journal of Mathematics, Science \& Technology Education, vol. 3, no. 1, pp. 35-39. ISSN: 1305-8223. 